\title{
Bireylerin Yardım Amaçlı Spor Etkinliklerine Katılım Güdüleri
}

\author{
Motivations for Participating in Charity Sport Events for Participants
}

\section{Fatma ÖZDAL*}

*Doktora Öğrencisi, Dokuz Eylül Üniversitesi, Sosyal Bilimler Enstitüsü, Turizm İșletmeciliği ABD, Kuruçeșme Mahallesi, Dokuz Eylül Üniversitesi, Kaynaklar Yerleşkesi, 35390, Buca, ìzmir.

E-posta: fatma.ozdal.ege@gmail.com

ORCID: 0000-0001-8779-3215

\section{MAKALE BILGILERI \\ Makale işlem bilgileri: \\ Gönderilme tarihi: 3 Nisan 2019 \\ Düzeltme: 20 Mayıs 2019 \\ Kabul: 2 Temmuz 2019 \\ Anahtar sözcükler: Yardım amaçlı spor etkinlikleri, Hayırseverlik, Pro- sosyal davranış, Spor etkinlikleri, Hayırseverlik turizmi, Güdüler.}

\section{ARTICLE INFO}

Article history:

Submitted: 3 April 2019

Resubmitted: 20 May 2019

Accepted: 2 July 2019

Key words: Charity sport events, Charity, Pro-social behavior, Sport events, Philanthropy tourism, Motivation.

\section{ÖZ}

Yardım amaçlı spor etkinlikleri, hayırsever birey veya kurumların, gereksinim sahiplerine bağış toplamada kullandıkları bir yöntem olarak ortaya çıkmıştır. Bireyler; içerisinde hayırseverliği ve fiziksel aktiviteyi bulunduran bu etkinliklere, farklı güdülerin etkisinde kalarak katılım göstermektedirler. Bu nedenle araștırmanın amacı; yardım amaçlı düzenlenen bir spor etkinliğine katılan bireylerin güdülerini tespit etmek olarak belirlenmiştir. Alanyazın taraması ışığında; İzmir'in Çeşme ilçesinde, kartopu örnekleme yöntemiyle yardım amaçlı düzenlenen bir bisiklet yarıșına (Veloturk Gran Fondo Çeșme Bisiklet Yarıșı) katılan 26 kiși ile yarı yapılandırılmıș derinlemesine görüșme yapılmıștır. Elde edilen verilere içerik analizi uygulanmıștır. Bulguların analizi sonucunda; hayırseverlik ve pro-sosyal davranış, etkinliğin yapıldığı yer (hayırseverlik turizmi), rekreasyonel ve spor ile ilgili güdülerin katılımda etkili olduğu sonucuna ulaşılmıştır. Özünde sporu barındırdığı için; sağıklı yaşam, rekabet, başarılı olma arzusu, hedonik dürtüler, yeteneklerin sınanması öncelikli katılım güdüleri arasında yer almıştır. Bununla birlikte; yardım amaçı spor etkinliklerinin topluma yarar sağladığı yönünde bulgular tespit edilmiştir.

\begin{abstract}
Charity sport events have occured as method for charitable organizations and philanthropic people. For these events in which include philanthropy and physical activity the participants are being influenced by different motivations. For this reason the aim of this study was to determine the motivation of people who participated in the charity sport events (Veloturk Gran Fondo Bycle Race in Cesme). Following the literature review, the primary data of the study has been collected through the execution of 26 in-depth and semi-structured interviews with chartiy sport events participants in Cesme by snowball sampling method. Content analysis was applied to the extracted data. According to the findings; philanthropy motivation, pro-social behavior, recreational motivations and an individual's involvement with the sport, the place in which the event is held (philanthropy tourism), were found as the effective reasons on participant. The main reasons is to participate in sport event, so that healthy life, competition, desire to be successful, hedonic impulses, testing of skills, priority motivations. Moreover, the findings show that charity sport events are beneficial for society.
\end{abstract}

\section{GiRiş}

Günümüzde bazı insanların hiç tanımadığı halde gereksinim sahiplerine yardım ettikleri, yardım kuruluşlarına bağışta bulundukları, kan bağışı yaptıkları veya kurtarma ekiplerine katıldıkları sıklıkla görülmektedir. Bireyin neden bu tür davranışlarda bulunduğu ile ilgili yapılan araştırmalar, pro-sosyal davranış kavramına işaret etmektedir (Benabou ve Tirole 2006). Sözcük anlamı birçok sözlükte karşılık bulmayan ve sosyal bilimciler tarafından anti-sosyal davranışın karşıtı olarak ortaya çıkan pro-sosyal davranış; kendinden başka bir veya daha fazla gereksinim sahibine yarar sağlamayı amaçlayan çeşitli eylemleri (yardım etme, paylaşma, teselli etme, bağışta bulunma vb.) kapsamaktadır (Batson ve Powell 2003). 
Pro-sosyal davranış kavramı çerçevesinde ele alınan yardım etme davranışı, farklı biçimlerde gerçekleşebilmektedir. Bunlardan biri olan yardım amaçlı spor etkinlikleri; dünyada uzun yıllardır, ülkemizde ise son yıllarda artan etkinlik sayılarıyla dikkat çekmektedir. Yardım amaçlı spor etkinlikleri; katılımcıların, toplumsal olarak önemli olan bir nedeni temel alarak kaynak yaratan ve bazı fiziksel egzersizleri içeren özel etkinlikleri temsil etmektedir (Filo vd.2011). Rekreasyonel bir faaliyet olarak bireyin ilgi duyduğu bir spora katılımı ile gerçekleştirilen spor etkinlikleri, toplumsal açıdan önemli değere sahip bir neden veya toplumsal yarar sağlamak amaciyla da düzenlenmektedir. Yardım amaçlı spor etkinliklerinde, katılımcılar belirli bir bağış ile koşu, bisiklet, yüzme yarışları vb. fiziksel aktivitelere katılabilmektedirler. Böylelikle bireyler hem sevdikleri, keyif aldıkları bir etkinliğe katılmakta, hem de bu etkinliği hayırsever bir amaçla birleştirmektedirler (Filo vd. 2019).

Ülkemizde yapılan yardım amaçlı spor etkinliklerinin bilimsel araştırmalarda çok fazla yer bulmadığı görülmektedir. Dolayısıyla, içerisinde sporu ve hayırseverlik kavramlarını barındıran yardım amaçlı spor etkinliklerine katılan bireylerin güdülerinin neler olduğunun araştırılması hem gelecek çalışmalar hem de bu etkinliklerle ilgili olarak önemli veriler sunacağından, alanyazına katkı sağlayacağı düşünülmektedir. Bu nedenle çalışmada son üç yıldır yardım amaçlı düzenlenen bir bisiklet yarışı etkinliğine katılan bireylerin, hangi güdülerle bu etkinliğe katıldıklarını ortaya çıkarmak amaçlanmıştır. Katılımcılarla görüşmeler sonucunda elde edilen bulgular, hayırseverlik temelli toplumsal yarar ve bir spor etkinliğinin sosyal etkileri ile olan ilişkisi göz önünde bulundurularak incelenmektedir.

\section{KURAMSAL ÇERÇEVE}

\section{Pro-sosyal Davranış Örneği Olarak Yardım Etme}

Kendinden başka, bir veya birden fazla gereksinim sahibinin yararına yapılan eylemlerin ve hayırseverliğin bütün çeşitlerini kapsayan prososyal (toplum yanlısı davranış) davranış kavra$\mathrm{m}$, insanın doğası üzerine gerçekleştirilen felsefi ve kuramsal tartışmalarda her zaman yer almıştır (Caprara ve Steca 2005). Bireyin ahlaki olmayan ve egoist eğilimlerinin, özgecil eğilimlerinden daha güçlü olduğu yönündeki tezlerin ortaya atılmasıyla başlayan bu tartışmanın, Kurt Lewin ve meslektaşlarının, 1930'larda ve 1940'larda modern sosyal psikolojiye başlamaları ve insanların gereksinim sahiplerine yardım etmediği bazı vakalarla karşılaşmalarıyla devam ettiği görülmektedir (Batson ve Powell 2003).

Pro-sosyal davranış olarak tanımlanan yardımlaşma davranışı; araştırmacılar tarafından özgecilik, empati, hedonizm, egoizm, karşılıklılık vb. kavramlarla ilişkilendirilerek açıklanmıştır (Mastain 2006). Birey, yardıma gereksinim duyan kişi yerine kendini (empati) koyduğu (Batsonve Powell 2003) veya bugün yapacağı yardımın ileride kendisine iyilikle döneceğini (karşılıklılık) düşündüğü için yardım davranışını gösterebilmektedir (Simpson ve Willer 2008). Öte yandan birey, yardım etme davranışını bir başkasının refahını artırma güdüsü olan özgecilik davranışıyla veya sadece kendi refahını arttırma güdüsü olan egoist davranışlarla da yapabilmektedir (Batson ve Powell 2003).

Diğerlerine yarar sağlayan ve kişinin dışarıdan herhangi bir ödül beklemeksizin yaptığı davranış biçimi olarak tanımlanan özgecilik (Midlarsky ve Kahana 1994) ve bu görüşe zıt olarak, özgeci davranışların doğrudan ödül, çıkar, bencillikle bağlantılı olduğunu ortaya koyan görüşler olmakla birlikte, başkalarına karşı hissedilen şefkat duygusunun, yardım etme güdüsünü tetiklediği de bilinmektedir (Yavuzer 2017). Tüm bu değerlendirmelerle beraber, yardım amaçlı düzenlenen spor etkinliklerine katılan bireylerin hangi güdülerle katılım gösterdiklerinin araştırıldığ 1 çalışmada, bireylerin katılım güdüleri,pro-sosyal davranış kuramı temelinde açıklanmıştır.

\section{Yardım Amaçlı Spor Etkinlikleri}

Yardım amaçlı spor etkinlikleri; bireysel olarak bir kayıt ücreti ödeme ve/veya belirli bir hayır işi için yapılan etkinlikle, bağış toplama olanağı sağlayan katılımlı spor etkinliğidir (Filo ve Coghlan 2016). Yardım amaçlı spor etkinlikleri, insanların arzu ettikleri bir hayır kurumu için para topla- 
ma firsatı olarak tanımlanmaktadır (Goodwin vd.2017; Filo vd. 2019).

Bireylerin boş zamanları boyunca kendi tercihleri doğrultusunda katıldıkları ve keyif aldıkları bir etkinlik türü olduğundan (Filo vd.2013), amaca dayalı (bireyin gereksinim sahiplerine yardim etme amacı) eğlenceyi ifade etmektedir (Filo vd.2008). Bir başka tanıma göre ise etkinliğe gönüllü olarak bağış toplamaya katılan bireyin hem hayırseverlik duygusunun etkisiyle hem de zevk duyduğu bir etkinliğe katılma isteğiyle bütünleşik bir etkinlik olarak tanımlanmaktadır (Lyons ve Wearing 2008).

Yardım amaçlı spor etkinlikleri, daha önceden belirlenmiş bir neden için (kanser hastaları, eğitim vb.) kaynak yaratan katılımcı bir spor etkinliğidir (Woolf vd. 2013). Etkinlikler boyunca farkındalık ve destek sağlamak amacıyla çeşitli aktiviteler düzenlenirken, katılımcılar arasında topluluk ve bir amaca hizmet etme hissi oluşturulabilmektedir (Filo vd. 2009; Wood vd. 2010; İnoue vd.2018). Bununla birlikte etkinliklerde genellikle bağ1ş toplama durumu, katılımcılar için zorunlu şart olarak sunulmazken, bağ1ş toplanmanın son derece önemli olduğu bilinmektedir (Filo ve Coghlan 2016).

Yardım amaçlı spor etkinliklerine dünyadan ve Türkiye'den iki örnek vermek mümkündür. “Wings for Life World Run" koşusu kâr amacı gütmeyen bir kuruluş tarafından dünyanın birçok noktasında düzenlenen ve omurilik felçlileri için bilim insanları tarafından yapılan araştırmalara destek sağlayan, yardım amaçlı bir spor etkinliğidir. Yardım amaçlı spor etkinliklerini Türkiye'de tanıtmak ve yaygınlaştırmak için kurulan ilk sivil toplum oluşumu olan "Adım Adım” ise oluşturduğu "İyilik Peşinde Koş” platformu ile sosyal sorumluluk projelerine (eğitim, çevre, hayvanlar, kanser hastaları vb.) maddi kaynak ve tanıtım desteği sağlamaktadır.

\section{ILGILI ÇALIŞMALAR}

Yardım amaçlı spor etkinlikleri, kâr amacı gütmeyen kuruluşların veya bireylerin bir araya gelerek gereksinim sahiplerine bağ 1 ş toplaması için yaptıkları etkinliklere dayanmakta ve bu tür etkinliklerin fiziksel aktivite eklenerek geliş- tirilen bir formu olarak ortaya çıkmaktadır (Filo vd. 2008; Won vd. 2010). İlgili çalışmaların 2000'li yıllarda başladığı görülen yardım amaçlı spor etkinlikleri; temelinde hayırseverliği, topluma yarar sağlamayı, bireyin ilgili olduğu spor nedeniyle katılımı gibi birçok güdü bulundurmakta, bununla birlikte bu duruma pro-sosyal ve özgecil davranışların, egoizmle bağlantılı olarak da hedonik dürtülerin etkili olduğu bilinmektedir (Bennett 2007; Filo vd. 2008). Bu güdülerle birlikte, yardım amaçlı spor etkinlikleri ile ilgili katılımcı güdülerini ortaya koyan araştırmalar Tablo 1'de gösterildiği gibidir:

Alanyazın taraması sonucunda, yardım amaçlı spor etkinliklerinin dünyada bilimsel araştırmalara sıklıkla konu olduğu tespit edilmiştir. Türkiye'de ise bu konuyla bağlantılı olarak bir araştırmanın (Yetim ve Işık 2016) yapıldı̆̆ı ve söz konusu araştırmada, bilimsel araştırma yöntemlerinden nicel yöntemin kullanıldığı belirlenmiştir. Hazırlanan anketle katılımcıların sadece hayırseverlik güdülerinin incelendiği araştırma, bu yönüyle mevcut araştırmadan ayrılmaktadır. Nitekim bu araştırmada; nitel araştırma yöntemi tercih edilmiş ve katılımcıların hangi güdülerle bu etkinliğe katıldıkları belirli bir anketle sınırlandırılmadan, derinlemesine görüşme yapılarak öğrenilmeye çalışılmıştır. Böylelikle birbirinden farklı ve çok sayıda katılım güdüsünün elde edilmesine olanak sağlanmıştır.

\section{YÖNTEM}

\section{Araştırmanın Önemi ve Amacı}

Konu ile ilgili alanyazın taramasına dayanılarak hazırlanan araştırmanın amacı; yardım amaçlı düzenlenen bir bisiklet yarışı etkinliğine katılan bireylerin, hangi güdülerle bu etkinliğe katıldıklarını ortaya çıkarmaktır. Bu amaç doğrultusunda çalışmanın araştırma sorusu; "Yardım amaçlı spor etkinliğine katılan bireyler, hangi güdülerin etkisinde kalarak bu katılımı sağlamaktadır?" olarak belirlenmiştir. Yardım amaçlı spor etkinlikleri ile ilgili yapılan araştırmaların son yıllarda artarak devam ettiği ancak ülkemizde bu alanda yapılan araştırmalara çok rastlanmadığı görülmektedir. Bu nedenle içerisinde sporu ve hayır- 
Tablo 1.Alanyazındaki Yardım Amaçlı Spor Etkinlikleri Katılımcı Güdüleri

\begin{tabular}{|c|c|}
\hline Yazar(lar)-YII & Katılımcı Güdüleri \\
\hline $\begin{array}{l}\text { Scott } \\
\text { ve } \\
\text { Solomon } \\
2003\end{array}$ & $\begin{array}{l}\text { Katılımcının "neden" ile bağlantısı, } \\
\text { Sosyal fayda, } \\
\text { Toplumsal yükümlülük, } \\
\text { Sağlıklı kalma isteği, } \\
\text { Kaynak yaratma/Bağış. }\end{array}$ \\
\hline $\begin{array}{l}\text { Bennett } \\
\text { vd. } \\
2007\end{array}$ & $\begin{array}{l}\text { "Neden"den dolayı kişisel katılım, } \\
\text { Sağlıklı bir yaşam tarzına öncülük etme isteği, } \\
\text { Bireyin söz konusu spora ilgisi, } \\
\text { Diğer katılımcılarla sosyal olarak bir araya gelme arzusu. }\end{array}$ \\
\hline $\begin{array}{l}\text { Filo } \\
\text { vd. } \\
2008 ; 2011\end{array}$ & $\begin{array}{l}\text { Boş zaman güdüleri (entelektüel, sosyalleşme ve yetkinlik/yeterlilik) } \\
\text { Hayırseverlik güdüleri (karşııklıık, benlik saygısı, başkalarına yardım etme gerekliliği ve } \\
\text { hayırseverliği geliştirmeye katkıda bulunma isteği). }\end{array}$ \\
\hline $\begin{array}{l}\text { Taylor } \\
\text { ve } \\
\text { Shanka } \\
2008\end{array}$ & $\begin{array}{l}\text { Başarma isteği, } \\
\text { Söz konusu spora olan ilgi, } \\
\text { Statü, } \\
\text { Sosyalleşme. }\end{array}$ \\
\hline $\begin{array}{l}\text { Won } \\
\text { vd. } \\
2010\end{array}$ & $\begin{array}{l}\text { Hayırseverlik, } \\
\text { Sosyalleşme, } \\
\text { Sağladığı yararlar, } \\
\text { Aile/arkadaşlarla zaman geçirme gereksinimi, } \\
\text { Spor, } \\
\text { Grup iş birliği/Ekibe destek. } \\
\text { Referans grup etkisi (aile veya arkadaş çevresinin etkisinde kalma). }\end{array}$ \\
\hline $\begin{array}{l}\text { Snelgrove } \\
\text { ve } \\
\text { Wood } \\
2010\end{array}$ & $\begin{array}{l}\text { İtici güdüler (başkalarını destekleme amacıyla katılım, etkinliğe bağılık nedeniyle katııım, } \\
\text { neden hakkında bilgi edinmek amacıyla katılım), } \\
\text { Çekici güdüler (fiziksel gücü test etme, bisikletçi kimliği (söz konusu spora olan ilgi), } \\
\text { sosyalleşme, destinasyonu keşfetme) }\end{array}$ \\
\hline $\begin{array}{l}\text { Coghlan } \\
2012\end{array}$ & $\begin{array}{l}\text { Açık güdüler (kaçış, sosyalleşme, macera, başarı, onaylanma isteği, arkadaşlık, özel ilgi) } \\
\text { Gizli güdüler (yaratıcılık (farklı veya yaratıcı sloganlar kullanmak, giyinmek vb.), } \\
\text { korkular ile yüzleşmek (trafikte bisiklet sürmek veya bir toplulukla yarı̧̧mak vb.)) }\end{array}$ \\
\hline $\begin{array}{l}\text { Chiu } \\
\text { vd. } \\
2016\end{array}$ & $\begin{array}{l}\text { Hayırseverlik, } \\
\text { Sosyal etkileşim, } \\
\text { Referans grubun etkisi, } \\
\text { Spora olan ilginin etkisi, } \\
\text { Nedenden dolayı katılım, }\end{array}$ \\
\hline $\begin{array}{l}\text { Yetim ve Işık } \\
2016\end{array}$ & $\begin{array}{l}\text { Hayırseverlik güdüleri (yardım etkinliğine katılım, etkinliğe katılmayı görev bilmek, } \\
\text { yardımcı olma huzuru). }\end{array}$ \\
\hline $\begin{array}{l}\text { Lee } \\
\text { vd. } \\
2017\end{array}$ & $\begin{array}{l}\text { Sosyal saygı, } \\
\text { Sağlık nedeniyle katılım, } \\
\text { Başkalarına yardım etme arzusu, } \\
\text { Hayır kurumuna yönelik beklenti. }\end{array}$ \\
\hline $\begin{array}{l}\text { Triantafyllidis } \\
\text { ve } \\
\text { Kaplanidou } \\
2019\end{array}$ & $\begin{array}{l}\text { Benlik saygısı, } \\
\text { Sağlığa sunduğu yararlar } \\
\text { Çevresel (toplumsal) kaygılar. }\end{array}$ \\
\hline
\end{tabular}


severlik kavramlarını barındıran bu etkinliklere katılan bireylerin güdülerinin neler olduğunun araştırılması, ülkemizde yapılan yardım amaçlı spor etkinliklerinin henüz yeni yeni yapılıyor olması nedeniyle, hem gelecek çalışmalar hem de bu etkinliklerle ilgili veriler sunacağından, alanyazına katkı sağlayacağı düşünülmektedir.

\section{Verilerin Elde Edilmesi}

Araştırmanın amacı doğrultusunda nitel araştırma yöntemi kullanılmıştır. Nitel araştırma; gözlem, görüşme ve doküman analizi gibi nitel bilgi toplama yöntemlerinin ve nitel bir sürecin izlendiği araştırma olarak tanımlanmaktadır (Yıldırım ve Şimşek 2013). Konuyu derinlemesine araştırmak, katılımcıların etkinliğe katılım güdülerini öğrenmek amaciyla bu yöntem tercih edilmiştir.

Araştırmada bilimsel çalışmalarda yaygın bir şekilde kullanılan veri toplama yöntemlerinden biri olan mülakat yöntemi kullanılmıştır ve etkinliğine katılan 26 kişi ile yarı yapılandırılmış derinlemesine mülakat (görüşme) yapılmıştır. Derinlemesine mülakat, araştırılan konunun bütün boyutlarını kapsayan, daha çok açık uçlu soruların sorulduğu ve detaylı cevapların alınmasına olanak veren, yüz yüze görüşülerek bilgi toplanmasını sağlayan, bir veri toplama tekniğidir (Tekin 2012). Yarı yapılandırılmış mülakat yöntemi ile katılımcıların, sistematik bir şekilde yöneltilen sorular ile konular hakkındaki düşüncelerinde ayrıntıya inebilmeleri amaçlanmıştır.

Hazırlanan mülakat formunda; katılımcıların yarışa katılım güdülerini öğrenmek için iki soru ve katılımcıları tanımlayıcı sorular yer almıştır. Mülakat soruları alanyazındaki çeşitli kaynakların (Bennett vd. 2007; Filo vd. 2008; Coghlan 2012; Filo vd. 2011; Chiu vd. 2016) incelenmesi sonucu oluşturulmuştur. Çeşme Belediyesi içerisinde kurulan kayıt alanında yapılan görüşmelerde, kişilere öncelikle araştırmanın amacından ve öneminden bahsedilerek, görüşme talebinde bulunulmuştur. Görüşme talebini kabul eden 26 katılımcı ile 3 Kasım 2018 tarihinde, araştırmacı tarafından yüz yüze görüşmeler gerçekleştirilmiştir. Yapılan görüşmeler sadece katılım güdülerini belirlemeye yönelik tanımlayıcı bilgiler ve iki (etkinliğin katılımcı için ne ifade ettiği ve katı- lım güdüleri) sorudan oluştuğu için yedi ile sekiz dakika arasında sürmüştür.

Mülakatlarda ses kayıt cihazı kullanılarak veri toplanmış ve tüm ses kayıtları yazılı hale getirilmiştir. Elde edilen veriler birkaç kez okunmuş, veri seti bir bütün olarak ele alınmış, notlar çıkarılmış, verilerden çıkarılan kavramlar alanyazın taramasından elde edilen kodlar ile kıyaslanarak değerlendirilmiştir. Görüşmeler sonrasında elde edilen verilere içerik analizi uygulanmıştır. İçerik analizinde görüşme, gözlem veya dokümanlar yoluyla elde edilen nitel araştırma verileri; kodlama, temaların bulunması, kodların ve temaların düzenlenmesi, bulguların tanımlanması ve yorumlanması olmak üzere dört aşamada analiz edilmektedir (Yıldırım ve Şimşek 2013).

Araştırma, güvenirlik ve geçerlik konusunda dikkat edilmesi gereken konular ışığında hazırlanmıştır. Nitekim araştırmacının görüşmeleri birebir yapması ve kayıt altına alması açısından araştırma yansızdır. Örneklem seçiminde evreni oluşturan bireylerin konuyla ilgili bilgilerine başvurulacak kişiler olması, farklı görüş ve kaynaklara ulaşılması ve araştırmacı dışında bir akademisyen tarafından araştırmanın teyit edilmesi, araştırmayı geçerli ve güvenilir kılmıştır.

\section{Evren ve Örneklem}

Araştırma sorusu kapsamında, İzmir'in Çeşme ilçesinde yardım amaçlı düzenlenen bir bisiklet yarışı araştırma alanı olarak belirlenmiştir. Yardım amaçlı ve amatör bisikletçilerin katıldı̆̆ yarış iki (47 km kısa, 100 km uzun) parkurdan oluşmaktadır. Toplamda 1545 (974 kısa parkur, 571 uzun parkur) kişi bu etkinliğe katılım göstermiştir ve toplam katılımcı sayısı araştırmanın evrenini oluşturmuştur. Araştırma alanının bu bisiklet yarışı olmasının nedeni bu etkinliğin son üç yıldır yapılıyor olması, hem dünyanın hem Türkiye'nin birçok yerinden, farklı yaş gruplarından gelen katılımcıların ve özellikle amatör bisikletçilerin katılabildiği bir etkinlik olmasıdır.

Çalışmanın veri toplama aşamasında görüşülecek kişilerin seçiminde tesadüfi olmayan örnekleme yöntemlerinden yargısal (amaçlı) örnekleme yöntemi kullanılmıştır. Bu yöntemin seçilme 
nedeni ise evreni en iyi temsil edebilecek, özellikle farklı yaşlarda, farklı parkurlarda ve farklı demografik özelliklerdeki bireyleri seçme isteğidir. Bu amaçla kartopu örnekleme yöntemi ile 26 kişiye ulaşılmıştır. Kartopu örnekleme yöntemi, öncelikle zengin veri elde edilebilecek kişileri tanıyan anahtar kișiye ulaşmakta, bu kişinin açacağ yolda devam eden araştırmacı, tavsiye edilen kişilere ulaşarak zinciri doğal olarak yeni kaynaklarla farklılaştırmaktadır (Creswell ve Poth 2007). Zincir içinde birkaç isimden tekrar tekrar söz edildikçe, bu zincir birleșmekte ve örneklem tamamlanarak evreni temsil etme gücüne ulaşmaktadır (Kothari 2004).

\section{BULGULARIN YORUMLANMASI}

\section{Tanımlayıcı Bulgular}

Mülakata katılanların altısı kadın, 20'si erkektir. Görüşme yapılan erkek katılımcıların yaşları 19 ve 65 , kadınların ise 21 ve 42 yaş aralığında değişmektedir. Görüşme yapılan katılımcıların 15'i kisa parkurda $(47 \mathrm{~km}), 11$ tanesi ise uzun parkurda $(100 \mathrm{~km})$ yarışmaktadır. Görüşme yapılan 26 kişinin dördü böyle bir etkinliğe ilk defa katıldığını, 22 kişi ise aynı etkinliğe birden fazla katılım gösterdiğini belirtmiştir. İzmir'den 12, İstanbul'dan yedi, Tekirdağ, Zonguldak, Mersin, Muğla, Ankara, Bursa ve İsviçre'den katılan birer yarışçı ile görüşme yapılmıştır. Katılımcıların 15 tanesi bir takımın üyesi olarak bu etkinliğe katılırken, 11 tanesi bireysel olarak katılmıştır.

\section{Hayırseverlik ve Pro-Sosyal Davranış ile ilgili Bulgular}

Alanyazındaki araştırmalarda hayırseverlik güdüleri; karşılıklılık, benlik saygısı, başkalarına yardım etme gereksinimi ve hayırseverliği sürdürme arzusu olmak üzere dört boyutta ele alınmıştır (Ritzenheim 2000). Bu doğrultuda analiz sonucunda hayırseverlik güdülerinden olan "benlik saygısı, başkalarına yardım etme gereksinimi ve hayırseverliği sürdürme arzusu" katılımcilar tarafından ifade edilmezken, pro-sosyal davranışın da temelinde olan karşılıklılık ve empati güdülerinin katılımda belirleyici olduğu tespit edilmiştir.

\begin{abstract}
"Fazladan bir çocuğun bile bisiklete bindiğini görmek çok önemli benim için, çünkü ben çok küçük yaşta sporu bırakmak zorunda kalmıştım ve bu benim içimde bir ukde olarak kaldı. 40 yaşımdan sonra yeniden başladım. Şimdi çocuklar için böyle şeylerin yapılması sevindirici." Mülakat 7

"Çocuklar şimdi bisikletle tanışırsa, büyüdüğü zaman daha aktif bir bisiklet kullanıcısı olarak başkalarını da spora teşvik edebilir."Mülakat 12
\end{abstract}

Katılım ücretinin gereksinim sahibi çocuklara bisiklet alınımında kullanılmasının, katılımc1lar için başlıca güdülerden biri(nedenden dolayı katılım) olduğu görülmektedir. Araştırmanın bu bulgusu, katılım güdülerinin "hayırseverlik" ve "nedene (amaca) bağlı" güdüler ile ilişkili olduğu yönündeki araştırmalarla paralellik göstermektedir (Bennett vd. 2007; Filo vd. 2008; Snelgrove ve Wood 2010; Won vd. 2010; Filo vd. 2011; Yetim ve Işı1k 2016; Chiu vd. 2016). Katılımcılardan biri konuyla ilgili şunları söylemiştir:

\footnotetext{
"Etkinlik katılım ücreti Türkiye şartlarında belli bir baremin üstünde ama çocuklara bisiklet hediyesi olduğu için hiçbir şekilde parayı düşünmeden kayıt oluyorum. Çocuklara bisiklet alınması, benim de çorbada bir tuzumun olması, mutluluk veriyor." Mülakat 12
}

Araştırmada elde edilen bulgular hayırseverlik güdüsü ve pro-sosyal (toplum yanlısı) davranışla ile bağlantılı olarak, yardım amaçlı spor etkinliklerinin ev sahibi toplum üzerinde sosyal etki ve sosyal destek sağladığını göstermektedir. Başkalarına verilen yardım ve koruma olarak tanımlanan sosyal destek (Langford vd. 1997); etkinliklerde elde edilen bağışlarla, katılım ücretleriyle gereksinim sahibi bireylere maddi malların bağışlanması (bisiklet alınması vb.) veya maddi olmayan (manevi destek vb.) desteğin sağlanması şeklinde yapılmaktadır. Sosyal etki ise topluma maddi olmayan yararlar (sosyal sermaye, ortak kimlikler, sağlık okuryazarlığı, refah ve beşeri sermaye) sağlamaktadır (Inoue ve Havard 2014). Yardım amaçlı spor etkinliklerinde sıklıkla karşılaşılan bu kavramlar, toplumun sosyal olarak güçlenmesini sağladığı için bu etkinliklerin bir parçası olarak incelenmektedir (Filo vd. 2009; Filo 2016). Bu anlamda toplumu spora teşvik etmek ve sağlıklı yaşama öncülük etmek, diğer katılım güdüleridir. Araştırmanın bu bulgusu alanyazındaki diğer araştırmaları desteklemiştir 
(Scott ve Solomon 2003; Bennett vd. 2007; Lee vd. 2017; Triantafyllidis ve Kaplanidou 2019). Özellikle bağış toplama amaciyla düzenlenen koşu, yüzme ve bisiklet yarışı gibi etkinlikler, sağlıklı yaşam tarzını teşvik ederken, ev sahibi topluluğun da yaşam kalitesini doğrudan etkilemede ve refahını arttırmada önemli katkılar sunmaktadır. Bu konuyla ilgili görüşlerini dile getiren katılımcılar şunları söylemişlerdir:

\footnotetext{
"Daha fazla insanın bisiklete bindiğini, özellikle çocuklara bisiklet sevgisinin aşılandığını görmek istiyorum. Biz millet olarak spora yabanciyız, hareket etmeyi, spor yapmayı sevmiyoruz. Etkinliğin, sporu sevdirmeye yönelik olması en keyifli bulduğum kısmı. Bu nedenle başka yerlerde, başka branşlarda da bu tarz etkinlikler yapılmalı."Mülakat 17

“Türkiye'de, insanlara bisiklet sporunun ne olduğunu öğreten bir etkinlik. Böyle spor organizasyonları sayesinde insanlar sporla tanışıyorlar. Örneğin ben bu yarışa katılmadan önce 114 kiloydum şimdi ise 82 kiloyum. Kolesterol, tansiyon her şey vardı, şimdi hiçbiri yok. Bu nedenle bu etkinliğe öncelikle sağlığ teşvik etmek için katıllyorum." Mülakat 20
}

Sosyal etki ve destek kapsamında ele alınan konulardan bir diğeri farkındalık yaratma kavramıdır. Nitekim yardım amaçlı spor etkinlikleri boyunca farkındalık ve destek sağlamak için çeşitli aktiviteler düzenlenebilirken (Filo ve Coghlan 2016), aynı zamanda katılımcilar arasında topluluk ve bir amaca hizmet etme hissi oluşturulabilmektedir (Filo 2009). Özetle birey, etkinliğin düzenlenme nedeni (gereksinim sahibi çocuklara bisiklet almak) veya aynı etkinlikte başka bir neden için farkındalık yaratmak isteyebilir. Bu anlamda katılım güdülerinden bir diğeri de farkındalık yaratmak olarak tespit edilmiştir. Bununla ilgili bir kadın katılımcı şunları söylemiştir:

\footnotetext{
"Ben bisikletli kadınların sayısı biraz artsın diye buradayım." 37 yaşındaki bir kadın neden araba kullanmıyor da bisiklet kullanıyor?" gibi yargılar var. Bu yargılar kendi kafamızda da oluşuyor. Bunları kırmak için de katılım önemli. Etkinlikte giyeceğim formanın üzerinde "follow the woman" yazıyor. Böylelikle mesajımla farkındalık yaratacağım." Mülakat 25
}

Son olarak yardım amaçlı düzenlenen etkinliklerde, etkinliği düzenleyenlerin, sponsorluk desteği veren kurum veya markaların ve hatta bu ekiplerle işbirliği yapan, çalışan veya herhangi bir şekilde iletişim halinde olan bireylerin bile "hayırseverlik" güdüsünü temel alarak, etkinli- ği düzenleyen ekip ile güçlü bir bağ kurdukları belirlenmiştir. Nitekim Filo ve arkadaşları (2018) etkinliği düzenleyen ekibin, yardım amaçlı spor etkinliklerine katılımında önemli bir etken olduğunu, yaptıkları araştırma ile ortaya koymuşlardır. Söz konusu araştırmada, etkinliğin sorunsuz, karşılıklı iletişimle ve bir amaca yönelik yapılıyor olmasının bu etkinliğe katılan bireylerde etkinliğe karşı "bağlılık" hissini kuvvetlendirdiği belirlenmiştir.

\begin{abstract}
“Bisiklet yarışlarını ve özellikle gereksinim sahibi çocuklar için ücretlerin kullanıldığını bildiğim için özellikle geliyorum, bu yüzden"Veloturk Gran Fondo Çeşme" ekibini çok seviyorum ve güveniyorum." Mülakat 11
\end{abstract}

Yukarıdaki ifadelerle paralel olarak etkinliğe katılımda, etkinliği düzenleyen ekibin önemli bir paya sahip olduğu ve bu yüzden de tekrar tekrar katılımın olduğu belirlenmiştir. Bu durumun tamamen yardım amaçlı bir etkinlikle ilişkili bir sonuç olduğu düşünülmektedir. Nitekim etkinliğin yardım amaçlı düzenleniyor olması, katılımcıların etkinlik düzenleyicilerine bağlığını güçlendirmekte ve yaşamlarında anlamlı bir yer edinmelerini sağlamaktadır (Filo vd. 2009).

\section{Etkinliğin Yapıldığı Yer ile IIIgili Bulgular}

Araştırmanın turizm destinasyonu olarak bilinen bir yerde (Çeşme) düzenlenen yardım amaçlı bir spor etkinliği olması, katılımcıların bu etkinliğe katılma güdülerinden birinin "etkinliğin yapıldığı yer" olarak belirlenmesine neden olmuştur. Bu bulgu Snelgrove ve Wood'un(2010) yaptıkları araştırmayı desteklemektedir. Nitekim söz konusu araştırmada da eğer yardım amaçlı bir spor etkinliği bir turizm destinasyonunda yapılıyorsa, bunun katılım için önemli bir güdü olduğu yönündedir. Bu konuyla ilgili katılımcılardan biri şunları söylemiştir:

\footnotetext{
“Türkiye'nin (Çeşme) en güzel coğrafyalarından birinde yapılan, en keyifli, doğa ile iç içe, güzel organize edilmiş bir etkinlik. Keyifle geliyorum. En büyük güdülerimden birisi Çeşme'nin çok güzel bir coğrafyaya sahip olması."Mülakat 11
}

Etkinliğin turizm destinasyonunda gerçekleştirilmiş olması katılımda etkili olsa da bazı katılımcılar etkinliğin yardım amaçlı düzenleniyor 
olmasının bunun önüne geçtiğini ve önemli bir "neden" den dolayı katılımında son derece etkili olduğunu dile getirmişlerdir. Bu bulgu daha önce yapılan çalışmaları desteklemektedir (Scott ve Solomon 2003; Bennett vd. 2007; Filo vd. 2009; Chiu vd. 2016).Katılımcilardan biri hem destinasyon hem nedenden dolayı katılımla ilgili şunları söylemiştir:

\footnotetext{
“Bu bisiklet yarışının bir benzeri başka bir yerde de yapılıyor ve bence orası daha güzel bir destinasyon ama takım olarak gitmedik, çünkü buradaki etkinlik yardım amaçlı yapılıyor, yaptığımız spora ve emeğimize daha çok değer katıyor" Mülakat 16
}

Yukarıdaki görüşmelerde görüldügü gibi hem hayırseverlik güdüsünün hem de Çeşme'yi görme güdüsünün birleştiği bir katılım söz konusudur.Bu tür seyahatler hayırseverlik turizmi olarak adlandırılmaktadır. Hayırseverlik turizmi (philanthropic tourism), turizm seyahati ile yardım amaçlı bağış toplama veya kaynak yaratma vesilesiyle düzenlenen bir etkinliğin birleştirildiği bir turizm şekli olarak tanımlanmaktadır (Coghlan 2011). Gönüllü olarak, farklı destinasyonlara giden turistler hem bağış yapmakta, hem gereksinim sahiplerine maddi manevi destek sağlamakta, hem de gittikleri yerlerde konaklama veya turistik yerlere geziler yaparak turizm faaliyetinin içerisinde yer almaktadırlar. Dolayısıyla elde edilen bu bulgu, yardım amaçlı spor etkinliklerinin bir turizm destinasyonunda yapılması durumunda, hayırseverlik turizmi ile bağlantılı olarak ele alınması gerekliliğini ortaya koymaktadır.

\section{Rekreasyonel Faaliyet ve Spor ile IIIgili Bulgular}

Etkinliklere katılımda; sosyalleşme, yeni arkadaşlıklar kurma, keyifli vakit geçirme ve günlük rutin işlerden kaçma isteği önemli güdüler olarak belirlenmiştir.Nitekim, yardım amaçlı spor etkinliklerine katılım güdülerinin araştırıldığı çalışmalarda Beard ve Ragheb'in (1983) geliştirdiği rekreasyonel faaliyet güdülerinin dört boyutu olan entelektüel, sosyalleşme, kaçış ve yetkinlik/yeterliğin temel alındığ1 görülmektedir (Bennett 2007; Filo vd. 2008; Won vd. 2010;Filo vd. 2011;Coghlan 2012). Mevcut çalışmada da bu dört güdünün etkili olduğu belirlenmiştir. Ente- lektüel (bilgiyi genişletmek, yeni şeyler keşfetmek vb.), sosyalleşme ve kaçış güdüleri ile ilgili katılımcılar şunları söylemiştir:

\begin{abstract}
"Hayatımda hiç bisiklet yarışına katılmamıştım ki yedi yaşımdan beri bisiklet kullanıyorum, ama dağ bisikletçisiyim bu yüzden farklı bir deneyim olsun diye katıldım." Mülakat 13

“Günlük rutinin dışında bir aktivite olarak gördüğüm ve hep birlikte eğlendiğimiz bir etkinlik. Sürekli kendi parkurumuzda kendi şehrimizde değil de yaklaşık bini aşkın kişiyle beraber farklı parkurda yarış1yoruz. Sosyalleşeceğimiz bir ortam oluyor. Başka şehirlerden arkadaşliklar ediniyoruz. Bunlar çok anlamlı duygular." Mülakat18
\end{abstract}

Spor etkinliklerine katılım güdülerinin temelinin bazı araştırmalarda hedonik gereksinimlerden ve bencil dürtülerden kaynaklandığg yönündedir (Funk ve James 2001). Bu araştırmada da katılımcların; rekreasyonel faaliyet kapsamında ele alınan ve bireyin arkadaşlarıyla bir etkinliğe katılıp eğlenceyi deneyimlemek, yeteneklerini s1namak, başarma ve rekabet etme gereksinimini karşılamak istemesinden dolayı katılım gösterdiği belirlenmiştir. Araştırmada elde edilen bu bulgu daha önce yapılan araştırmalarla paralellik göstermektedir (Filo vd. 2008; Taylor ve Shanka 2008; Won vd. 2010; Snelgrove ve Wood 2010; Filo vd. 2010; Coghlan 2012). Konu ile ilgili katılımcılar şunları söylemişlerdir:

\footnotetext{
"Geçen sene kısa parkurda yarıştım. Bu sene uzun parkurda kendimi denemek istediğim için bu yarışa katıldım."Mülakat 5

“Bu etkinliğe katılmak için antrenmanlar yaptım. Dolayısıyla artık kendimi test etme zamanının geldiğini düşünüyorum. Bakalım geçen sene ile bu sene arasında neler fark etmiş?"Mülakat14
}

Bennett ve arkadaşlarının (2007) yardım amaçlı spor etkinliklerine katılan bireylerin güdülerinin araştırıldığı çalışmalarında katılımcıların sosyal olarak bir araya gelme arzuları ile birlikte söz konusu spora ilgilerinin olması, önemli bir katılım güdüsü olarak ortaya çıkmıştır. Bu çalışma ile paralel olarak etkinliğin bisiklet yarışı merkezli olmasının, bireylerin katılımını etkilediği tespit edilmiştir. Katılımcılardan biri etkinliğe bisiklet sporu ve söz konusu spora ilgisi olduğu için katılım gösterdiğini şu sözlerle ifade etmiştir: 
"Bisiklet ve bisikletin verdiği özgürlük duygusu, bisiklete binmenin benim için ayrı bir önemini olması, bu etkinliğe katılmamdaki en etkili güdüler." Mülakat 3

Alanyazındaki diğer katılım güdülerinden farklı olarak bu araştırmada; etkinliğin amatör katılımcılara açık olması, özellikle orta yaşın üzerindeki bireylerin de bu etkinliğe katılım göstermeleri ve etkinliği düzenleyen ekip içerisinde tanınmış bir ismin olması farklı sonuçlara ulaşılmasına katkı sağlamıştır. Bu konularla ilgili katılımcılar şunları söylemiştir;

\footnotetext{
"Ben çocukluğumdan beri bisiklete biniyorum. O yüzden yaşım gereği birçok yarışta benim yaş grubuma göre bir kategori yok. Bu yüzden bu etkinlik benim yaş kategorisindeki (65) bireyler için önemli."Mülakat 8

"Veloturk Gran Fondo Çeşme ekibine güvenim sonsuz ve özellikle Arda Türkmen'i çok seviyorum, bu nedenle de bu etkinliklere katılıyorum."Mülakat 11
}

Yukarıdaki görüşmelerde ifade edildiği gibi etkinliğin kimler tarafından yapıldığından, kimlerin bu etkinliklere başvurabileceğine, hangi sporun etkinlikte yapılacağına veya etkinliğin nerede yapiliyor olduğuna kadar birçok unsurun katılım güdülerini etkilediği görülmektedir.Dolayısıyla, etkinliklere daha fazla bireyin katılması için bu unsurların göz önünde bulundurulması gerekmektedir. Böylelikle daha fazla katılım sağlanarak, daha fazla bağış veya katılım ücreti ile daha fazla gereksinim sahibine ulaşmak mümkün olacaktır.

\section{SONUÇ}

Yardım amaçlı spor etkinliklerine katılım güdülerinin araştırıldığ 1 çalışmada, üç ana katılım güdüsü (hayırseverlik ve pro-sosyal davranış, etkinliğin yapıldığı yer, rekreasyonel ve spora olan ilgi) belirlenmiştir. Araştırmanın bu sonucu konuyla ilgili alanyazındaki diğer araştırmaları desteklemiştir (Scott ve Solomon 2003;Bennett vd. 2007; Filo vd. 2008; Snelgrove ve Wood 2010; Won vd. 2010; Filo vd. 2011; Yetim ve Işık 2016; Chiu vd. 2016). Özünde sporu barındırdığı için; sağlıklı yaşam, rekabet, başarılı olma arzusu, bir ekibin üyesi olarak katılım, hedonik ve bencil dürtüler, yeteneklerin sınanması gibi güdüler öncelikli katılım güdüleri arasında yer almıştır.
Karşılıklılık ve empati önemli katılım güdüleri arasında yer alırken, hayırseverlik güdülerinden olan "benlik saygısı, başkalarına yardım etme gereksinimi ve hayırseverliği sürdürme arzusu" katılımclar tarafından ifade edilmemiştir. Bu yönüyle söz konusu hayırseverlik güdülerinin önemli katılım güdüleri olduğunu ortaya koyan araştırmalardan (Filo vd. 2008; Taylor ve Shanka 2008;Filo vd. 2011) ayrılmıştır. Öte yandan hayırseverlik temelli yapılan bu etkinliklere katılımda; farkındalık yaratma ve "neden" den dolayı katılımın olduğu belirlenmiştir. Etkinliğin Çeşme gibi bir turizm destinasyonunda yapılması ise bir diğer katılım güdüsüdür. Hayırseverlik turizmi (philanthropic tourism) olarak değerlendirilen bu durum, bireyin bağışçısı olduğu etkinliğe hem destinasyonu tanımak ve keşfetmek hem de yardım amaçlı gitmesini içermektedir.

Pro-sosyal davranış kapsamında ele alınabilecek yardım amaçlı spor etkinliklerine katılım güdüleriyle ilgili alanyazında birçok araştırmanın yapıldığı görülmektedir. Yurtdışında yapılan çalışmalardan farklı olarak bu araştırmada, etkinliği düzenleyen ekip içerisinde tanınmış birinin olması ve yaş aralığının geniş tutulması nedeniyle oluşan bir katılım güdüsü olduğu tespit edilmiştir. Ülkemizde ise bu konuyla ilişkili bir araştırmanın yapıldığı ve bu araştırmanın sosyal pazarlama kapsamında ele alındığı görülmektedir. Yetim ve Işı $k^{\prime} ı n$ (2016) yaptığ 1 araştırmada uygulanan anket formunda sadece hayrrseverlik güdülerine yer verilmiş ve diğer katılım güdülerinin neler olduğu araştırılmamıştır. Dolayısıyla araştırma hem bu yönüyle hem de kullanılan yöntem nedeniyle, mevcut araştırmadan ayrılmıştır. Böylelikle bu araştırma Türkiye'de yardım amaçlı yapılan bir spor etkinliğine katılan bireylerin hangi güdülerle bu etkinliklere katıldığına yönelik yapılan ilk çalışma olmuştur.

Görüşmelerin Çeşme Belediyesi içerisindeki kayıt alanında yapılması, araştırmanın zaman ve mekân kısıtını oluşturmuştur. Gelecek çalışmalar,farklı ve daha geniş örneklemlerle gerçekleştirilebilir. Bununla birlikte gelecek çalışmalar için, söz konusu etkinliklerin sadece katılımcı nezdinde değil, bu etkinlikleri organize eden ekipler, etkinliklerin yapıldığı destinasyon- 
larda yaşayan halk, yerel yönetimler ve bu tür etkinliklerin yapılmasına destek sağlayan sponsorlar nezdinde de ele alınması önerilebilir.

\section{KAYNAKÇA}

Batson, C.D. ve Powell, A.A. (2003). Altruism and Prosocial Behavior. İçinde T. Millon ve M.J. Lerner (Editörler), Handbook of Psychology (ss.463-484). Amerika Birleşik Devletleri: John Wiley and Sons.

Beard, J.G. ve Ragheb, M.G. (1983). Measuring Leisure Motivation, Journal of Leisure Research, 15(3):219-228.

Benabou, R. ve Tirole, J. (2006). Incentives and Prosocial Behavior, American Economic Review, 96(5):1652-1678.

Bennett, R., Mousley, W., Kitchin, P. ve Ali-Choudhury, R. (2007). Motivations for Participating in Charity-Affiliated Sporting Events, Journal of Customer Behaviour, 6 (2):155-178.

Caprara, G.V. ve Steca, P. (2005). Self-Efficacy Beliefs as Determinants of Prosocial Behavior Conduciveto Life Satisfaction Across Ages, Journal of Social and Clinical Psychology, 24(2):191-217.

Chiu, W., Lee, Y.J. ve Won, D. (2016). Bifactor Analysis of Motivation for Charity Sport Event Participation, International Review on Public and Nonprofit Marketing, 13(1):113.

Coghlan, A. (2012). An Autoethnographic Account of a Cycling Charity Challenge Event: Exploring Manifest and Latent Aspects of the Experience, Journal of Sport and Tourism, 17(2):105-124.

Coghlan, A. (2011). Adventure Philanthropy Triallinga New Blend of Tourism and Volunteering. In Cauthe 2011: National Conference: Tourism: Creating a Brilliant Blend (ss.108-120). Güney Avustralya: University of South Australia School of Management.

Creswell, J.W. ve Poth, C.N. (2007). Qualitative Inquiry and Research Design:Choosing A-among Five Approaches. Londra: Sage Publications.

Filo, K., Fechner, D. ve Inoue, Y. (2019). Charity Sport Event Participants and Fundraising: An Examination of Constraints and Negotiation Strategies, Sport Management Review, 17(2):105-124.

Filo, K. ve Coghlan, A.(2016). Exploring the Positive Psychology Domains of Well-Being Activated Through Charity Sport Event Experiences, Event Management, 20 (2):181-199.

Filo, K., Spence, K. ve Sparvero, E.(2013). Exploring the Properties of Community among Charity Sport Event Participants, Managing Leisure, 18(3):194-212.

Filo, K., Funk, D.C. ve O’brien, D. (2011). Examining Motivation for Charity Sport Event Participation: A Comparison of Recreation-Based and Charity-Based Motives, Journal of Leisure Research, 43(4):491-518.

Filo, K., Funk, D.C. ve O'brien, D. (2009). The Meaning Behind Attachment: Exploring Camaraderie, Cause, and Competency at a Charity Sport Event, Journal of Sport Management, 23(3):361-387.
Filo, K. R., Funk, D.C. ve O'brien, D. (2008). It's Really not about the Bike: Exploring Attraction and Attachment to the Events of the Lance Armstrong Foundation, Journal of Sport Management, 22(5):501-525.

Funk, D.C. ve James, J. (2001). The Psychological Continuum Model: A Conceptual Framework for Understanding an Individual's Psychological Connection to Sport, Sport Management Review, 4(2):119-150.

Goodwin, A., Snelgrove, R., Wood, L. ve Taks, M.(2017). Leveraging Charity Sport Events to Develop a Connection to a Cause, Event Management, 21(2):175-184.

Inoue, Y., Heffernan, C., Yamaguchi, T. ve Filo, K. (2018). Social and Charitable Impacts of a Charity-Affiliated Sport Event: A Mixed Methods Study, Sport Management Review, 21(2):202-218.

Inoue, Y. ve Havard, C. T. (2014). Determinants and Consequences of the Perceived Social Impact of a Sport Event, Journal of Sport Management, 28(3):295-310.

Kothari, C.R. (2004). Research Methodology: Methods and Techniques. New Delhi: New Age International.

Langford, C.P.H., Bowsher, J., Maloney, J.P. ve Lillis, P.P. (1997). Social Support: A Conceptual Analysis, Journal of Advanced Nursing, 25(1):95-100.

Lee, C.J., Sced, P.M. ve Chen, M.H. (2017). Does Sponsoring Charity Sport Events Improve Customer Behavioral Intention?, International Journal of Management, Economics and Social Sciences, 6(2):107-120.

Lyons, K. ve Wearing, S. (2008). Allfor a Good Cause? The Blurred Boundaries of Volunteering and Tourism, Journeys of Discovery in Volunteer Tourism, (2000):147-154.

Mastain, L. (2006). The Lived Experience of Spontaneous Altruism: A Phenomenological Study, Journal of Phenomenological Psychology, 37(1):25-52.

Midlarsky, E. ve Kahana, E. (1994). Altruism in Later Life. Amerika Birleşik Devletleri: Sage Publications.

Ritzenhein, D.N. (2000). One More Time: How Do You Motivate Donors?, New Directions for Philanthropic Fundraising, (29): 51-68.

Scott, A. ve Solomon, P.J. (2003). The Marketing Of CauseRelated Events: A Study of Participants as Consumers, Journal of Nonprofit and Public Sector Marketing, 11(2):4366.

Simpson,B. ve Willer,R. (2008). Altruism and Indirect Reciprocity: The Interaction of Person and Situation in Prosocial Behavior, Social Psychology Quarterly, 71(1):37-52.

Snelgrove, R. ve Wood, L. (2010). Attracting and Leveraging Visitors at a Charity Cycling Event, Journal of Sport and Tourism, 15(4):269-285.

Taylor, R. ve Shanka, T. (2008). Cause for Event: Not-forprofit Marketing Through Participant Sports Events, Journal of Marketing Management, 24(9-10):945-958.

Tekin, H. H. (2012). Nitel Araştırma Yönteminin Bir Veri Toplama Tekniği Olarak Derinlemesine Görüşme, Sosyoloji Dergisi, 3(13):101-116.

Triantafyllidis, S. ve Kaplanidou, K. (2019). Marathon Runners: A Fertile Market for "Green" Donations?, Journal of Global Sport Management, (2019):1-14. 
Yavuzer, N. (2017). Bir Pro-sosyal Davranış Kaynağı Olarak Özgeci Motivasyonun İlgili Alan Yazını Işığında Değerlendirilmesi, Hasan Ali Yücel Ĕ̆itim Fakültesi Dergisi, 14(1):105.

Yetim, Ç.A. ve Işık, A.D. (2016). Sosyal Amaç Bağlantılı Etkinliklere Katılımı Etkileyen Başlıca Motivasyon Faktörleri: Fethiye Yaşam İçin Yarış Örneği, Journal of International Social Research, 9(43):1766-1775.

Yıldırım, A. ve Şimşek, H. (2013). Sosyal Bilimlerde Nitel Araştırma. Ankara: Seçkin Yayınları.
Wood, L., Snelgrove, R. ve Danylchuk, K. (2010). Segmenting Volunteer Fundraisers at a Charity Sport Event, Journal of Nonprofit and Public Sector Marketing, 22(1):38-54.

Woolf, J., Heere, B. ve Walker, M.(2013). Do Charity Sport Events Function as "Brandfests" in The Development of Brand Community?, Journal of Sport Management, 27(2):95-107.

Won, D., Park, M. ve Turner, B.A. (2010). Motivations for Participating in Health Related Charity Sport Events, Journal of Venue and Event Management, 1(1):17-44.

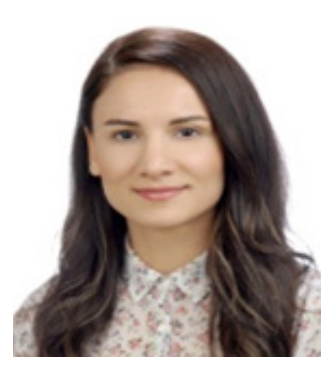

Fatma ÖZDAL

Ege Üniversitesi Çeşme Turizm ve Otelcilik Yüksekokulu, Konaklama Işletmeciliği Bölümü’nden mezun oldu (2013). Yüksek lisans derecesini Dokuz Eylül Üniversitesi Sosyal Bilimler Enstitüsü Turizm İşletmeciliği Ana Bilim Dalı'ndan aldı (2016). Yüksek lisans eğitimini tamamlayarak Dokuz Eylül Üniversitesi Turizm İşletmeciliği Ana Bilim Dalı Doktora Programı́na başladı (2017). Halen aynı kurumda doktora eğitimine devam etmektedir. Temel çalışma alanları; Turizm Pazarlaması, Müze Yönetimi ve Etkinlik Yönetimi'dir. 